\title{
PRELIMINARY RESULTS OF THE GEOPHYSICAL SURVEYS OF THE NETWORK OF DEFENCE SETTLEMENTS FROM THE BRONZE AGE BETWEEN THE BIEBRZA AND NAREW (NE POLAND)
}

DOI: https://doi.org/10.18509/AGB.2020.06

UDC: 904:725.96" "637"

\author{
Krzysztof Żurek ${ }^{1}$, Tomasz Kalicki ${ }^{1}$, Paweł Przepióra' ${ }^{1}$, \\ Marcin Frączek ${ }^{1}$, Jakub Niebieszczański ${ }^{2}$, Cezary Bahyrycz ${ }^{2}$, \\ Slawomir Chwałek ${ }^{3}$, Aleksander Piasecki ${ }^{4}$, Adam Wawrusiewicz ${ }^{4}$
}

\author{
${ }^{1}$ Institute of Geography and Environmental Sciences, Jan Kochanowski University in Kielce, Poland \\ ${ }^{2}$ Faculty of Archaeology, Adam Mickiewicz University in Poznań, Poland \\ ${ }^{3}$ Student Science Club of Geomorphologists ,Złoty Bażant”, Jan Kochanowski University in Kielce, Poland \\ ${ }^{4}$ Department of Archaeology, Podlaskie Museum in Biatystok, Poland
}

corresponding author:

submitted: 10.02 .2020

accepted: 15.04 .2020

published: 15.06 .2020

\begin{abstract}
This paper presents the results of geophysical research (geomagnetic and GPR) and preliminary hypotheses concerning "Valley Forts" type settlements in the cultural landscape of the Biebrza-Narew river valleys, in the Bronze Age, which were developed on the base of the results of geophysical research of selected sites. Non-invasive identification of this type of sites was carried out using the magnetometric prospecting method. Two sites in the Biebrza river valley (Jatwieź Duża) and Narew river valleys were selected. The map of distribution of magnetic anomalies allowed to outline the organization and structure of sediments in the horizontal dimension. Magnetometric images of the sites show a complicated arrangement of objects. A number of types of anomalies have been registered, out of which those describing the defensive character of fortified settlements point to stone and earth structures. At least two lines of fortifications have been registered for all the stands, manifesting themselves as linear groupings of anomalies, thus contradicting any possible cavities in the type of ditch or moat. In addition, the distribution of the anomalies indicates the existence of clear gaps in the fortification lines, which can be interpreted as entrances to the settlement or gateways. These objects clearly indicate the anthropogenic character or adaptation of this place for defensive purposes in the form of terracing and strengthening of slopes. This is indicated by multiple anomalies, which form concentric assumptions of the palisade/wooden and stone embankment type or their combinations.
\end{abstract}

Keywords: Valley Forts, Narew Valley, Biebrza Valley, geophysical prospecting method,

\section{INTRODUCTION}

The remains of defensive (fortified) settlements have been an important element of the cultural landscape of Podlasie for a long time. This type of objects is most often connected with the Middle Ages. The year 2017 brought a change, when several new structures of this type were discovered. The prospection of the digital elevation model (DEM) registered 25 new, related settlement forms - "Valley Forts". They constitute, in the territory of NE Poland (Podlasie), a complex settlement network in an extensive system of Narew and Biebrza river valleys [6], [10], [11], [12]. All these objects are located within the river valleys and have a similar structure (Fig. 1). These forms were constructed in a coherent system, and their classification was made possible by their morphological features (a) and topographical location (b):

(a)the design of all structures is characterized by a circular or slightly oval centre surrounded by one, two or three rings of embankments;

(b)all facilities are located within Narew and Biebrza river valleys or their smaller tributaries. They are poorly visible in the relief, which is probably a result of a significant denudation processes as well as anthropogenic factors [10], [11], [12]. It is assumed that objects of this type are defensive settlements of Urnfield Culture Circle, as shown by analogies from other excavation sites from the region [2], [9], [10], [11], [12].. 

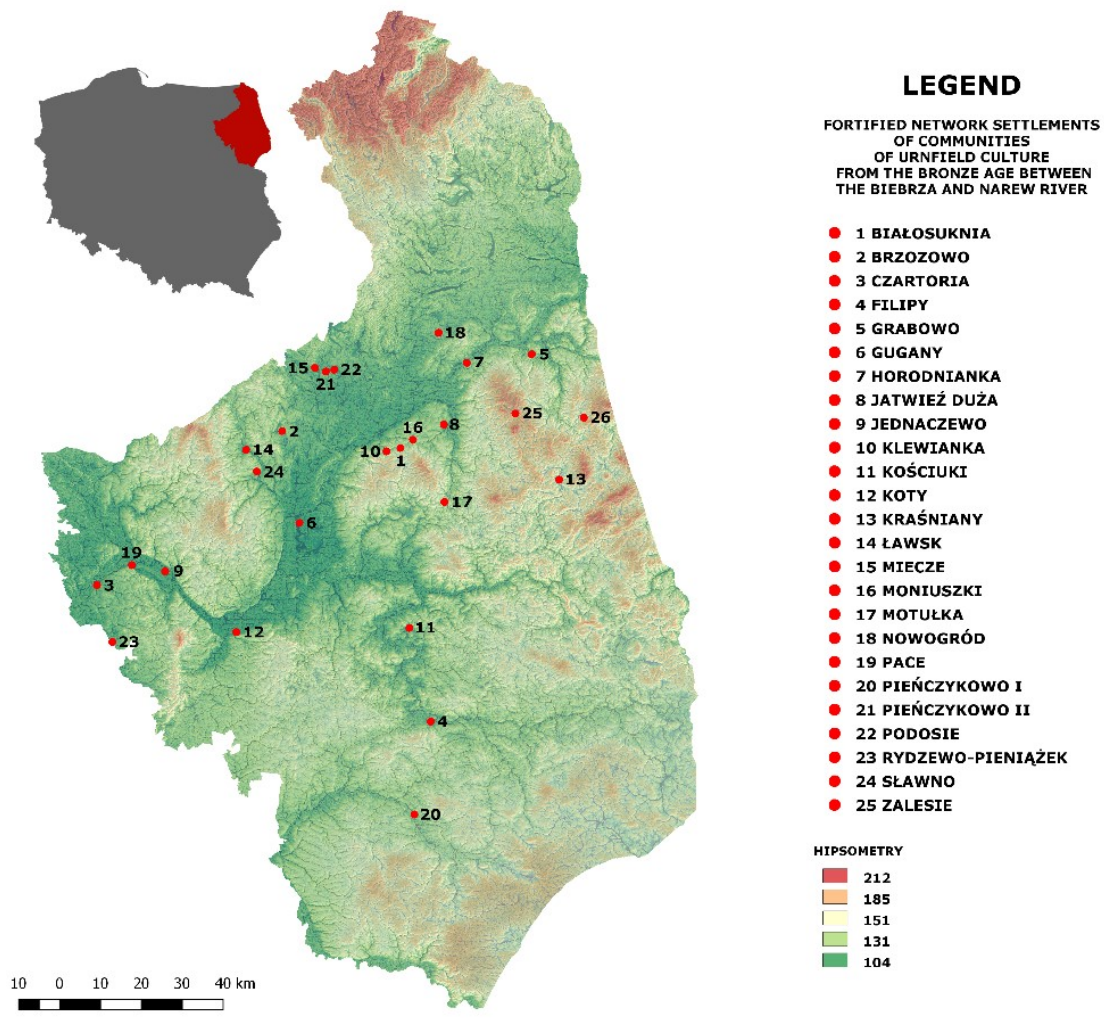

Figure 1. Location of study area (red arrows) in NE Poland, Podlasie province

\section{AIM OF STUDY AND METHODS}

The main objective of this paper is to present the results of geophysical research (geomagnetic and GPR) and to present preliminary research hypotheses concerning "Valley Forts" type settlements in the cultural landscape of the BiebrzaNarew River, in the late Bronze Age and early Iron Age, which were developed on the base of the results of geophysical research of selected sites.

Two sites were selected to presents preliminary results - one located in the north in the Biebrza river valley (Jatwieź Duża) [1], [4] and second located in the south in the Narew river valley (Filipy) [8], [3] in to identify records of human activity related to Prehistoric settlements, especially in the Late Bronze Age and Early Iron Age (Fig. 1). Examined objects may include structural elements of the fortification, such as stones or their concentrations, wooden structures (palisades, box forms) or moat ditches or earth embankments.

Considering the nature of expected structures related to the settlement, the magnetometric method and later verification of selected areas with the use of the GPR method were used.

\section{RESULTS}

Jatwieź Duża - results of magnetometer surveys The resultant image of magnetometric prospection at this site, which is the result of field work and
The applied research methodology allows to register the said groups and classes of objects on the flat plan [1], [3], [4], [8], [10], [11], [12].

The measurements were done within the grid of the measuring fields, so-called grids, which was founded on selected positions and was common for magnetometric and GPR. Each grid was a square of $20 \mathrm{~m}$ sides, surveying with a Leica RTK GPS receiver (Leica NetRover GS08/CS10). Magnetometric measurements were made using Bartington equipment (Fluxgate), model Grad-601, while the georadar surveys were made using Mala GeoScience ProEx System equipment (Professional Explorer) with a $500 \mathrm{MHz}$ antenna.

The results of geophysical surveys were carried out in two levels. In the first stage magnetometric surveys were carried out on the surface of all selected objects. The data from these measurements were visualized in GeoPlot program, which allowed for the selection of grids for GPR research. In the second stage, GPR studies were started and the results of the collected data were developed in the Ground Vision and Reflex programs..

office analyses carried out with the use of specialized software, is characterized by the complexity of recorded readings (1 in Fig. 2) [1]. 


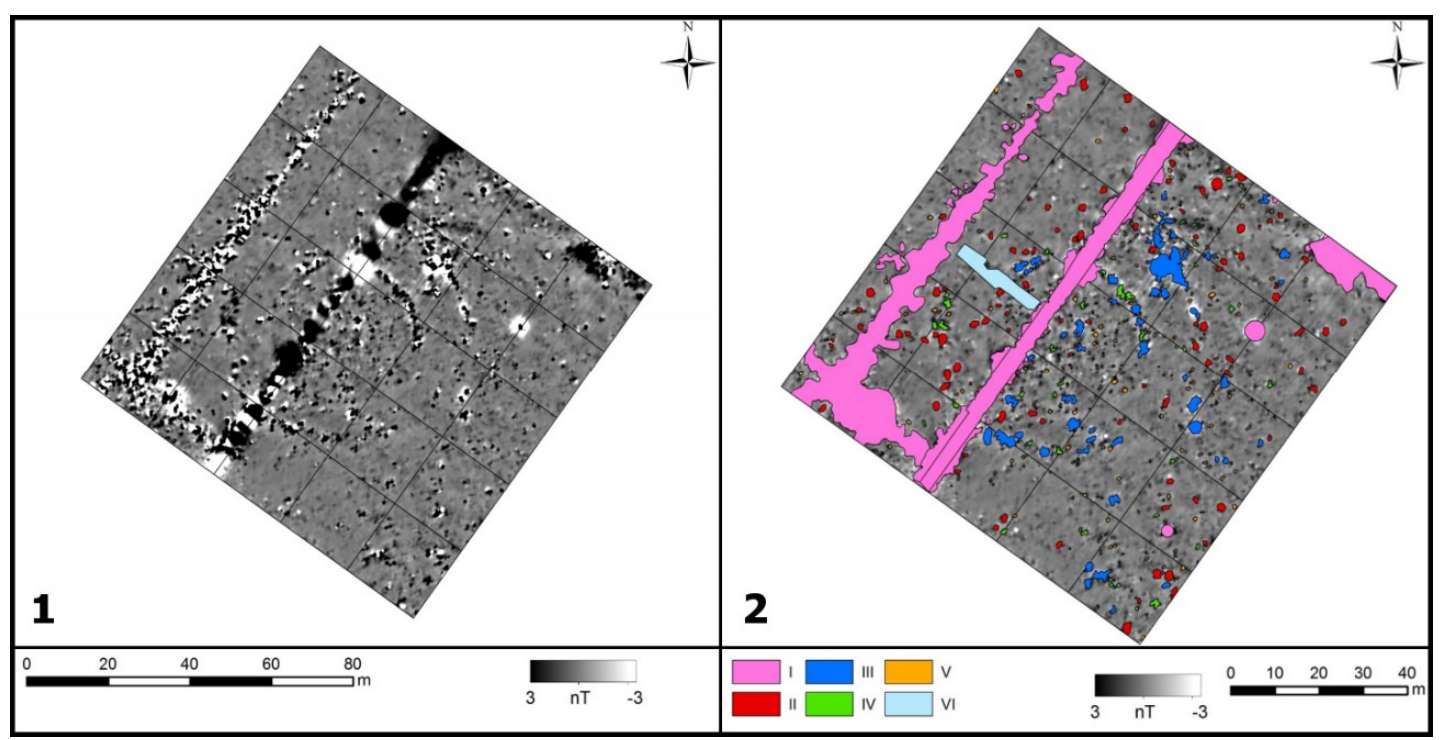

Figure 2. The results of magnetometric prospectus at the Jatwieź Duża site. Value range nT: -3 / 3 (1), Graphic interpretation of the magnetometric image at the Jatwieź Duża site. Distribution of six types of anomalies (2)

The range of values of recorded signals, their number, differentiation in terms of magnetic properties and the grouping itself, made it possible to distinguish six classes of readings - polygonal anomalies which their groupings forming linear arrangements (2 in Fig 2) [1].

Type I - high readings of bipolar nature and mostly unspecified magnetic fields. The most readable and easy to interpret anomalies are those running through, more or less, the middle of the site on the SW-NE axis. The objects generating the described strong signals are metal wires attached to wooden piles dug into the ground, forming a fence of individual plots (2 in Fig 2) [1]. Bipolar signals located in the eastern corner of the research area were also classified into the group of such anomalies.

Type II - bipolar signals with separating centers, which makes it possible to specify individual objects generating such readings. The values of the recorded signals are in the range from -50 to $50 \mathrm{nT}$. They should be interpreted as boulders containing ferrimagnetic minerals. Some of the signals in this category are part of the supposed defensive structures, strengthening their interpretation as boulders or stones (2 in Fig 2) [1].

Type III - bipolar signals of an unspecified nature of the emitting center. They generate wide ranges of values magnetization in the range from -50 to 50 $\mathrm{nT}$. The highest frequency of their occurrence is within the boundaries of a recognizable object. They represent a large variety of shapes and sizes. Often these readings have overlapping fields magnetic, which directs recognition of their origin towards the accumulation of boulders or stones ( 2 in Fig 2) [1]. Type IV - positive anomalies, with an unspecified and heterogeneous shape on a flat plan of the resulting magnetometer image. The range of values that has been registered by the measuring device is positive and reaches a maximum of $50 \mathrm{nT}$. These signals were located mainly in the fort structure under study, as well as in its immediate context. It should be connected with the activity of the Prehistoric human being in the area and his deliberate actions (2 in Fig 2) [1].

Type V - one-field anomalies with positive magnetic field values. They are quite homogeneous in terms of shapes and sizes - the vast majority of them are circular, oval and relatively small. They have a fairly wide spatial distribution on study area, however, their greater concentration occurs within the studied Prehistoric structure, especially its central part. They can be pit holes or smaller boulders lying below the surface (2 in Fig 2) [1].

Type VI - this category is created by only one broad-plane traverse anomaly. It is located in the central-western part of the studied area and crosses two alleged circles of fortifications on the SE-NW axis. Has a regular outline with increased value of magnetization. Comparing the collected data with the results of excavations carried out at the site in 2018, it should certainly be considered a registered anomaly as a signal generated by the backfill of the archeological survey excavation (2 in Fig 2) [1].

\section{Jatwieź Duża - results of GPR surveys}

The research area of the site was divided into two sections J_1 and J_2 each with dimensions of 20x40 $\mathrm{m}$ for GPR research based on geomagnetic data (Fig. 3). The results obtained show anomalies that overlap in part with the results obtained during magnetic research. The measurements recorded on them can probably be associated with linear constructions, such as stone and wooden embankments [4]. Two types of anomalies were identified in both studied space. 


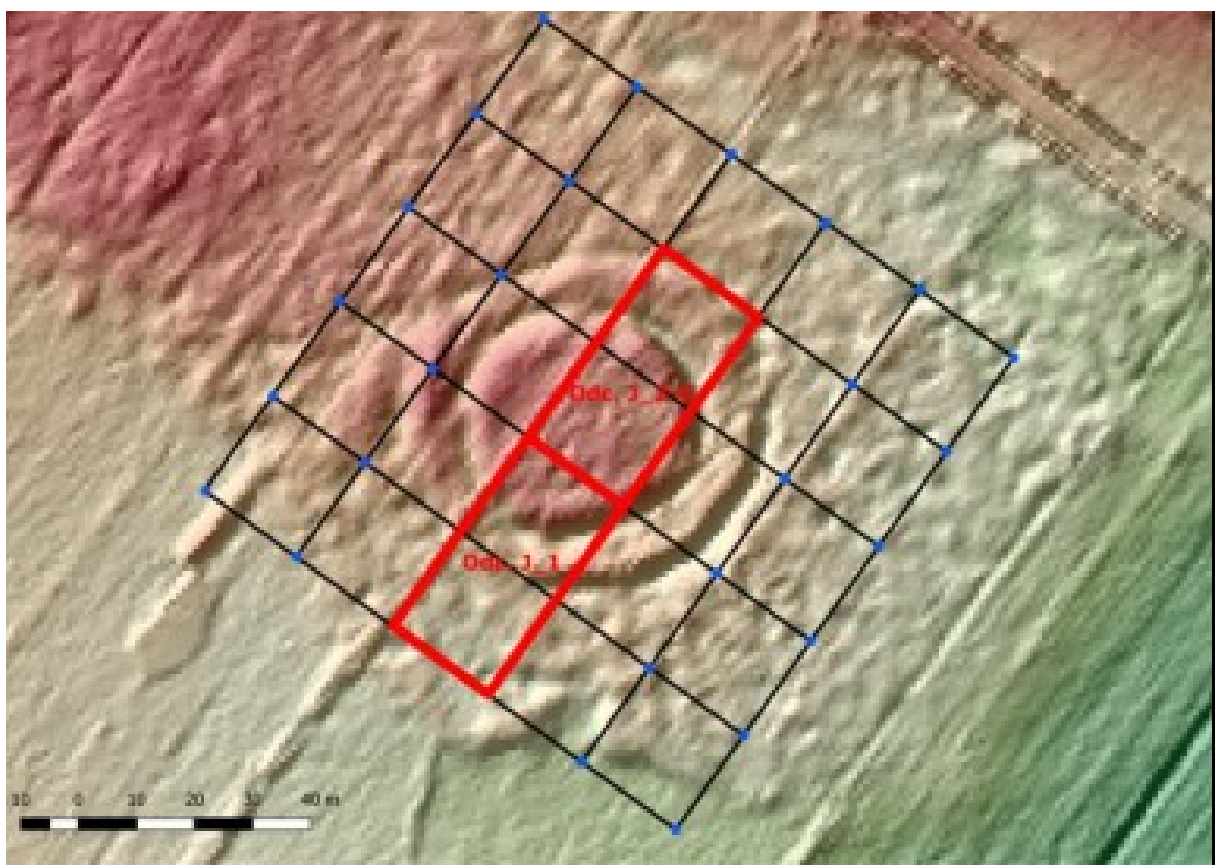

Figure 3. DEM of the Jatwieź Duża site with location of areas for georadar research (GUGiK data)

Type I - anomalies forming a polygonal linear system. It coincides with the data from the DEM. The measurements recorded on them can probably be associated with linear constructions, such as stone and wooden embankments (A2 \& B2 in Fig. 4) [4].

Type II - polygonal anomalies that do not form a linear system. Most of them are characterized by a strong signal from the central core. These can be large objects such as stones as well as remnants of other infrastructure of the object. Another explanation may be the remnants of pit holes, especially within the central square of the site (A2 \& B2 in Fig. 4) [4].

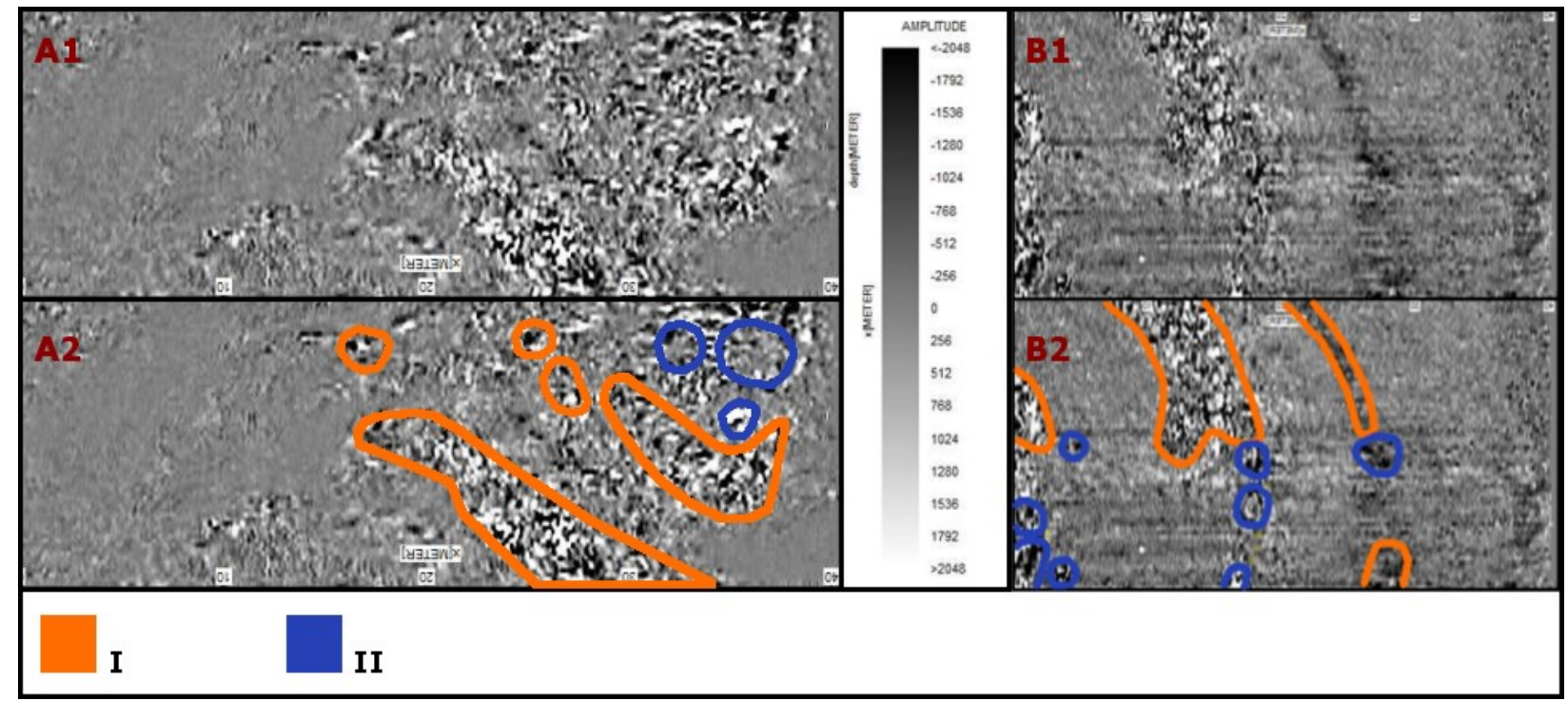

Figure 4. Section J_1 (A1 and A2). Processed image from the depth of about $1.0 \mathrm{~m}$ Section J_2 (B1 and B2) Processed image from the depth of about $1.20 \mathrm{~m}$

\section{Filipy - results of magnetometer surveys}

The magnetometric image of the site has relatively low complexity in terms of recorded values (Fig. 2 $\& 5$ ). Considering the number of anomalies, diversity in terms of magnetic properties, field orientation and grouping, it was decided to describe them under four types of polygonal anomalies (Fig. 5) [8]. 


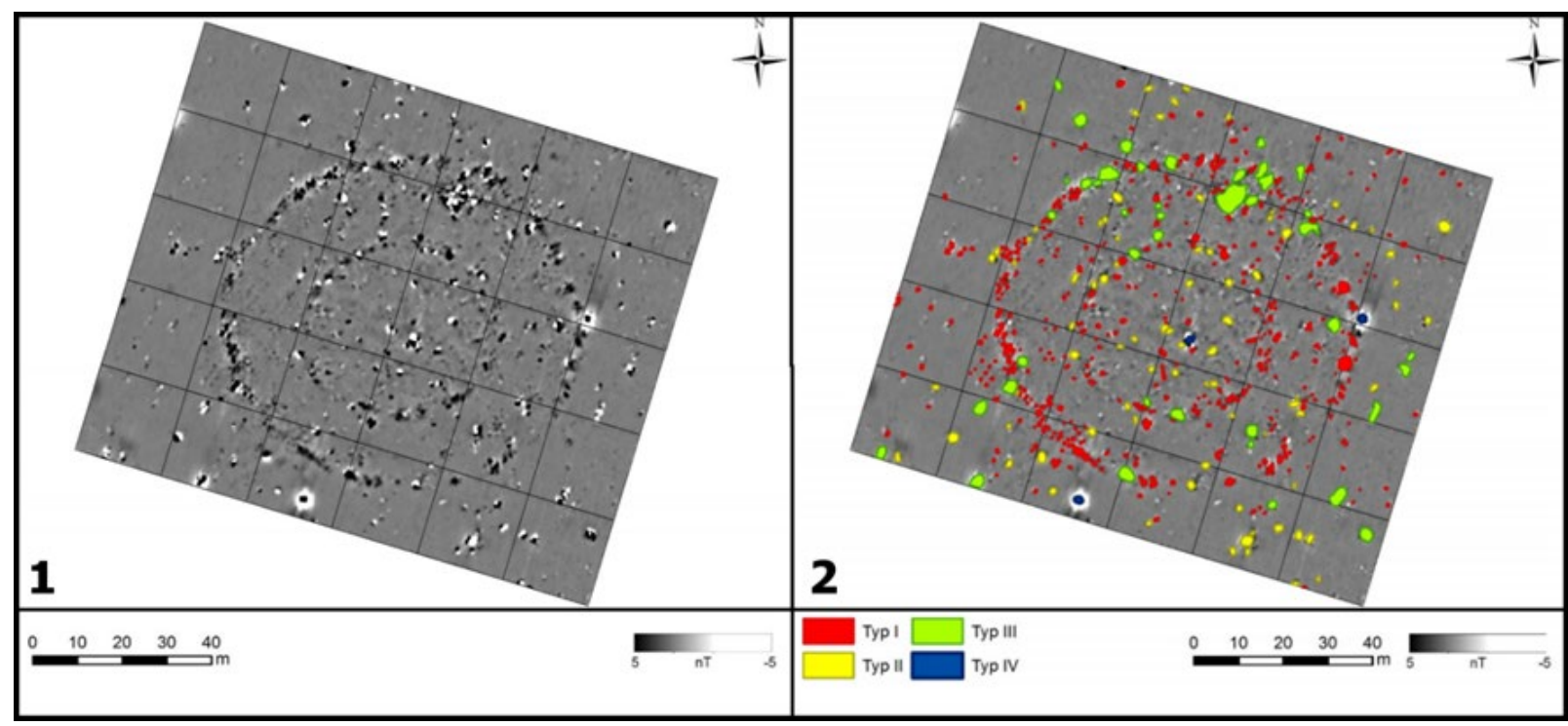

Figure 5. The results of magnetometric prospectus at the Filipy site. Value range nT: -5 / 5 (1). Graphic interpretation of the magnetometric image. Distribution of four types of anomalies (2)

Type I - have a single magnetic positive center, and do not have a clearly regular shape. Their dimensions range from a few $\mathrm{cm}$ to over $2 \mathrm{~m}$ in diameter. Distribution of these objects can be observed throughout the area research. However, the most visible are their circular-shaped concentrations in the central part of the area (two concentric strips consisting). This can be interpreted as places of occurrence of differences in sediment lithology, which may indicate the presence of pit holes. They may also be boulder positions used for construction of fortifications or other objects (2 in Fig. 5) [8].

Type II - This anomaly is two-field structures with a clearly visible positive and negative center of magnetization value. A significant concentricity of both fields is visible, which suggests the type of remnant magnetization. The dimensions of these anomalies range from a dozen or so $\mathrm{cm}$ to a few meters in diameter that crosses both fields $(+/-)$. Most of the anomalies are between -30 and $30 \mathrm{nT}$. This type was interpreted as small metal waste. In addition, these structures should not be treated as modern objects because of the expected chronology of the site (Late Bronze Age/Early Iron Age). Therefore, it can be assumed that these anomalies may also signal the position of iron artifacts (2 in Fig. 5) [8].

Type III - Anomalies are similar to those of type two in terms of magnetization values. It was decided to distinguish them based on the different shape and arrangement of negative and positive centers. In all cases, these anomalies are much larger from type two and often reach several meters in length or diameter. Characterized by heterogeneity and a significant degree of overlapping fields. The concentration of objects with strong magnetic properties may be responsible for such a manifestation in the image. This group includes, for example, boulders with a high content of ferromagnetic minerals and as well as in an archaeological context it could be a burned clay or burned wooden constructions ( 2 in Fig. 5) [8].

Type IV - Three anomalies were also recorded on the magnetometric image, which are certainly associated with modern human activity. These are characterized signals a clear and high positive center, and a concentrically divergent center negative all around (2 in Fig. 5) [8] .

\section{Filipy - results of GPR surveys}

On the sections under analysis anomalies whose shape does not coincide with the ALS map were recorded. In the first section of $F_{-} 120 \times 40 \mathrm{~m}$ (A1 $\& \mathrm{~A} 2$ in Fig. 7). Legible anomalies can be observed only below $2 \mathrm{~m}$ deep. This is probably related to the heavily transformed area. The readability of the echograms at this depth is clear enough to distinguish the outlines of supposed linear objects - outline of shafts, moats or other structures [3]. 


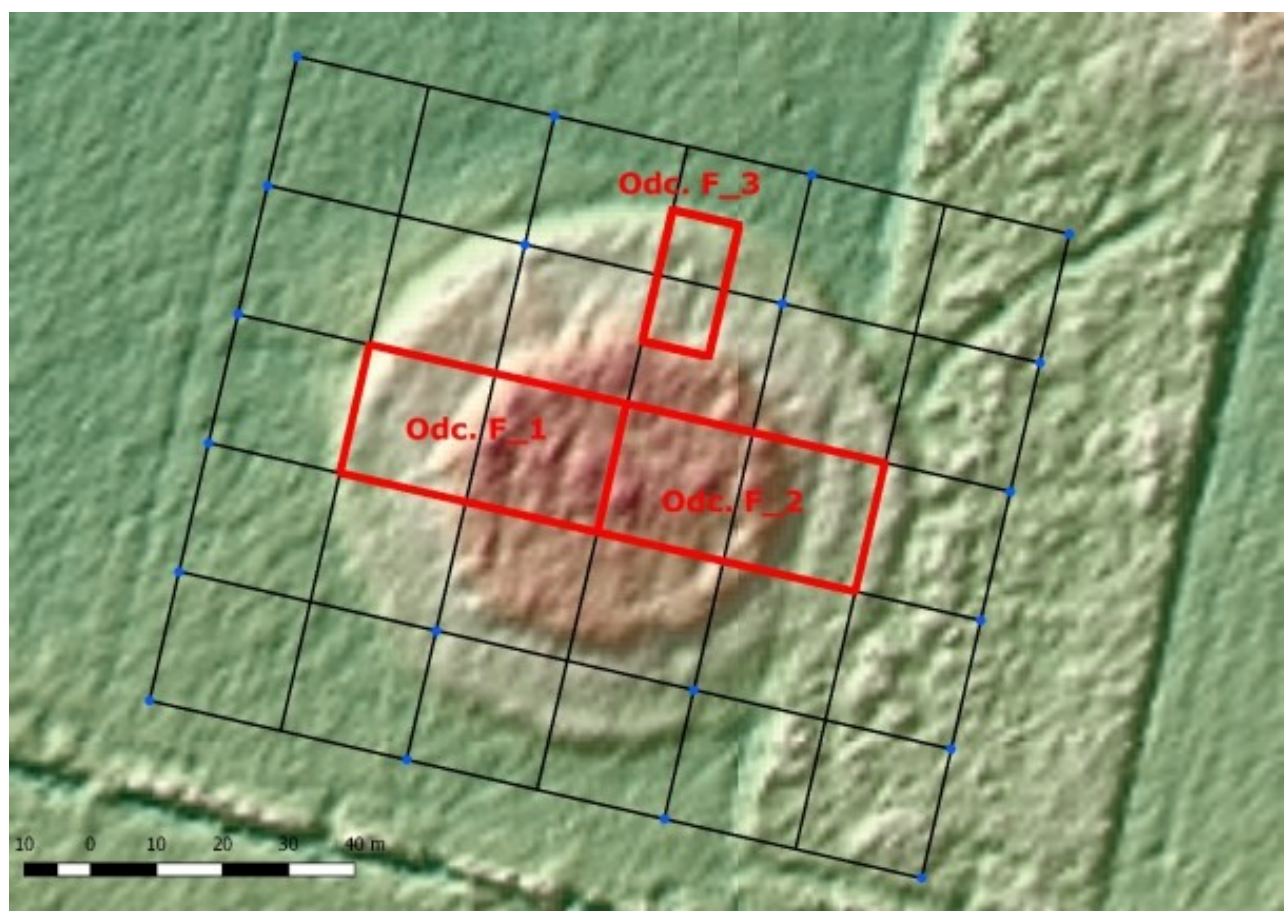

Figure 6. DEM of Filipy site with location of areas for georadar research (GUGiK data)

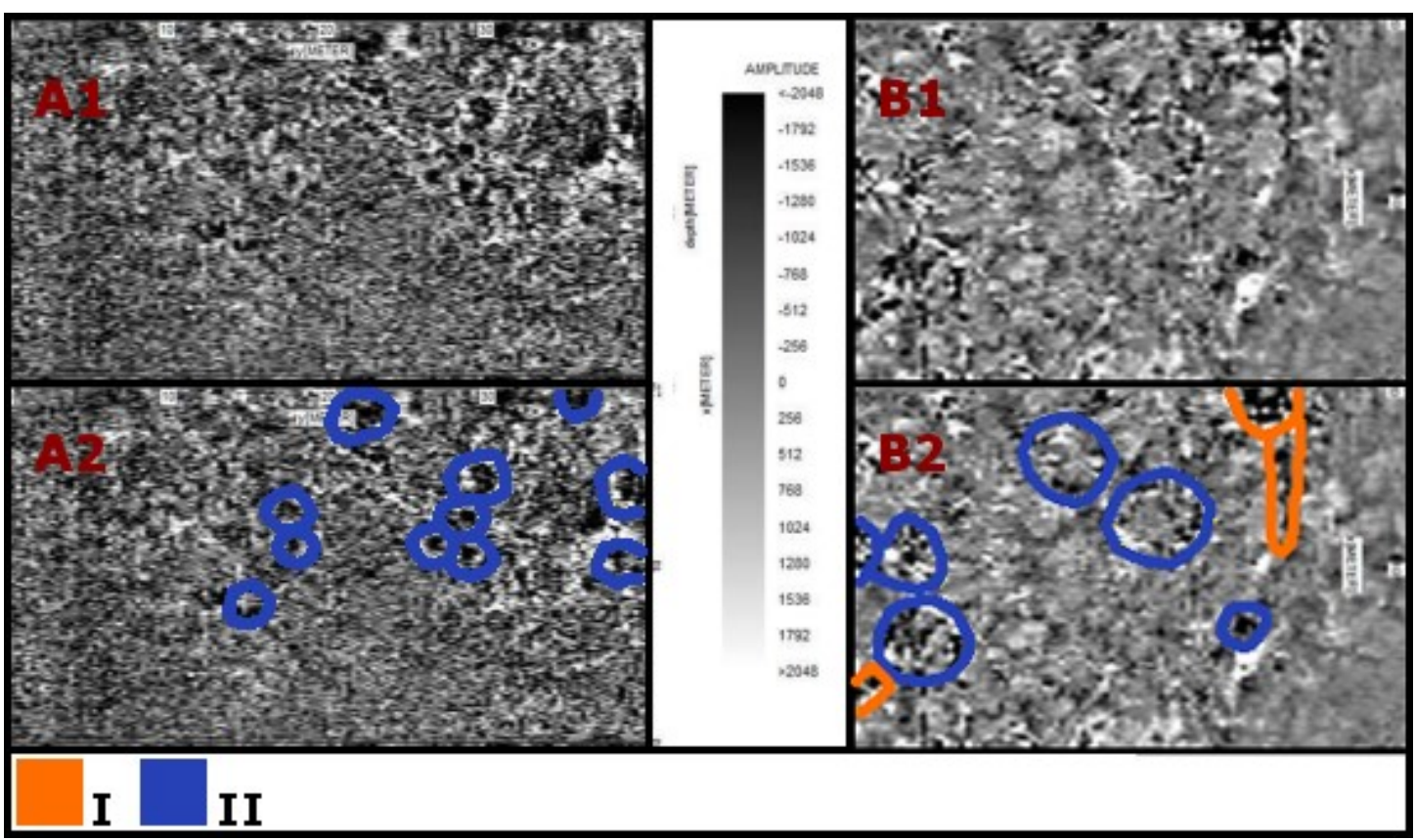

Figure 7. Section F_1 (A1 and A2). Processed image from the depth of about $2.20 \mathrm{~m}$ Section F_2 (B1 and B2). Processed image from the depth of about $2.00 \mathrm{~m}$

On the section of 20x40 m, marked F_2 (20x30 m) and F $3(20 \times 10 \mathrm{~m}),(\mathrm{B} 1 \& \mathrm{~B} 2$ in Fig. 7$)$, six levels with anomalies were generated, whose legibility starts from $1.15 \mathrm{~m}$ and $1.60 \mathrm{~m}$, and ends at about $2.4 \mathrm{~m}$ depth [3]. Two types of anomalies are separated - type I, field anomalies that do not form linear structures and type II, anomalies whose layout refers to linear structures (Fig 7). The image of this site obtained by means of the GPR prospectus is very distorted. The most interesting results were obtained in section $\mathrm{F} 3$ (Fig 8). At a depth of $1 \mathrm{~m}$ to $2.4 \mathrm{~m}$ polygonal anomaly appears.
A rectangular polygonal anomaly is observed at depths of $1 \mathrm{~m}$ to $2.4 \mathrm{~m}$. It may be interpreted as a residue of some complex structure (gateway?) [3], [8]. The reason for obtaining such ambiguous images of GPR measurements may be the environment condition. The lithological structure on which the site is located as well as the high groundwater level [3], [5], [7]. However, anomalies were reported at individual levels, probably related to the settlement and fortifications (embankments or moat). 


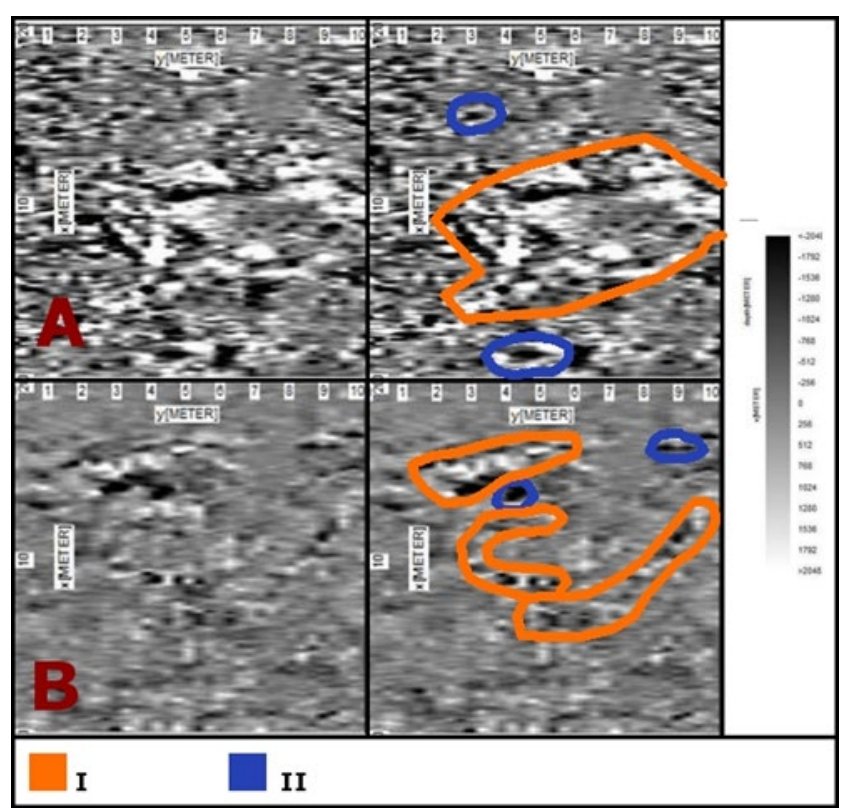

Figure 8. Section F_3. Processed image from the depth of about $1.0 \mathrm{~m} \mathrm{(A)}$ and $2.4 \mathrm{~m}(\mathrm{~B})$

\section{DISCUSSION AND CONCLUSIONS}

As part of non-invasive geomagnetic reconnaissance, a rich pool of various types of polygonal anomalies was recorded at both sites, which in a broader context create linear systems. Their regular arrangement is evidence of anthropogenic origin, which in addition, based on a flat plan, can be called defensive [1], [3], [4], [8]. Two concentric circles composed of anomalies are clearly visible, which testify to the presence of stones, burnt wooden structures or also pits or burnt clay (Fig 2, A2 \& B2 in Fig 4, Fig. 5, B2 in Fig. 7). Most of the anomaly, perfectly corresponds to the DEM made on the basis of data made available by aerial laser scanning. At both examined stands they coincide with the outline of the fortification ramparts from the model of the area. Results obtained from magnetometric and GPR measurements it has become possible to trace the installation sequence and to determine the number of embankments. At least two regular fortification districts (external and internal) have been confirmed.

Important from the point of view of the reconstruction of human activity in the past in the studied area are the polygon anomalies recorded in the central part of the facilities, which do not create any linear arrangements in themselves (Fig 8). In this case, the obtained image of geo-radar surveys enhances the interpretation of these types of anomalies as the remains of a pit holes.

The results of geophysical research give a picture of a defence settlements which, in the Bronze and Iron Age, could be used by human communities not only as a refugium.

\section{REFERENCES}

[1] Bahyrycz C., Niebieszczański J., Badania magnetometryczne na stanowisku w Jatwieźi Dużej. Raport, IA UAM, Poznań, 2019

[2] Dąbrowski J. Epoka brązu w północno-wschodniej Polsce, Białystok, 1997

[3] Kalicki T., Przepióra P., Chwałek S., Żurek K. Opracowanie georadarowe stanowiska Filipy. Raport, ZGGKS, Kielce, 2019

[4] Kalicki T., Przepióra P., Chwałek S., Żurek K. Opracowanie georadarowe stanowiska Jatwieź Duża. Raport, ZGGKS, Kielce, 2019

[5] Karczewski J. Zarys metody georadarowej, Kraków, 2007

[6] Kondracki J. Geografia Polski: regiony fizyczno-geograficzne, Wydawnictwo Naukowe PWN, Warszawa, 2014.

[7] Misiewicz K. Geofizyka archeologiczna, IAiE PAN, Warszawa, 2006

[8] Niebieszczański J., Bahyrycz C., Badania magnetometryczne na stanowisku w Filipach. Raport, IA UAM, Poznań, 2019 
[9] Pawlata L. Stanowisko kultury łużyckiej w Popowlanach, gm. Tykocin, pow. białostocki, Zeszyty Podlaskie, vol. 5, pp 55-95, 2009.

[10] Żurek K., Kalicki T., Wawrusiewicz A., Frączek M., Przepióra P., Piasecki A. \& Piasecka K. „Valley Forts” in Poldasie river valleys - preliminary archaeological and paleogeographical results on the Jatwieź Duża archaelogical site, 24. Kvarter, Brno, pp 70, 2018.

[11] Żurek K., Kalicki T., Niebieszczański J., Chwałek S., Frączek M., Przepióra P., Wawrusiewicz A., Piasecki A., Bahyrycz C. Results of geophysic (geomagnetic and geo-radar) surveys of the network of defence settlements from the bronze age betwen the Biebrza and Narew, 25. Kvarter, Brno, pp 64, 2020

[12] Żurek K., Kalicki T., Frączek M., Przepióra P., Wawrusiewicz A., Piasecki A. \& Piasecka K. Fenomen założeń obronnych typu „Valley Forts” w dolinach Podlasia - wstępne wyniki badań geoarcheologicznych ze stanowiska Jatwieź Duża, 20. MISSA, Poznań, pp 48, 2019 